\title{
Structural violence and the nature of cemetery-based skeletal reference collections
}

\author{
Greer Vanderbyl Simon Fraser University, BC, Canada \\ John Albanese University of Windsor, ON, Canada \\ Hugo F. V. Cardoso Simon Fraser University, BC, Canada \\ hcardoso@sfu.ca
}

\begin{abstract}
The sourcing of cadavers for North American skeletal reference collections occurred immediately after death and targeted the poor and marginalised. In Europe, collections sourced bodies that were buried and unclaimed after some time in cemeteries with no perpetual care mandate, and may have also targeted the underprivileged. The relationship between socio-economic status (SES) and abandonment was examined in a sample of unclaimed remains (603 adults and 98 children) collected from cemeteries in the city of Lisbon, Portugal, that were incorporated in a collection. Results demonstrate that low SES individuals are not more likely to be abandoned nor to be incorporated in the collection than higher SES individuals. Furthermore, historical data indicate that the poorest were not incorporated into the collection, because of burial practices. Although the accumulation of collections in North America was facilitated by structural violence that targeted the poor and marginalised, this phenomenon seems largely absent in the Lisbon collection.
\end{abstract}

Key words: poverty, ossuary, unclaimed remains, temporary graves

\section{Introduction}

Human skeletal reference collections are integral to research in human skeletal biology, bioarchaeology and forensic anthropology, as they combine a large quantity of human remains with their respective ante-mortem documentation of sex, age and other data such as cause of death. Well-documented collections are essential for developing new research methods, testing the validity of old ones and addressing population-specific research questions. ${ }^{1}$ Such collections are stored and curated in a variety of public and private universities and museums for the purposes of research and education. ${ }^{2}$ While documentation certainly makes collections valuable for research purposes, individuals that comprise these collections are not necessarily representative of the living society from which they were derived. ${ }^{3}$ Skeletal collections are a product of the biological and social attributes of the individuals within them, ${ }^{4}$ so no two collections will be the same, as they represent segments of 
populations within a specific historical context. The sampling method for inclusion in any collection is more likely to include certain individuals, making collections biased towards the types of people targeted by the collection process. ${ }^{5}$

In North America, skeletal reference collections are often comprised of unclaimed, unburied bodies. Most individuals included in these collections, especially in large industrial cities, were unemployed African American men or foreign immigrants who died of diseases such as tuberculosis or pneumonia. ${ }^{6}$ Poverty was a large and socially visible problem in early nineteenth-century America. The practices of poor relief and dissection eventually became intertwined as the bodies of the institutionalised poor became legal and illegal targets of medical schools for the procurement of anatomical specimens. ${ }^{7}$ Eventually, many of those cadavers ended up in skeletal reference collections. As such, the use of these unclaimed remains has been interpreted as a form of structural violence inflicted upon the poor. ${ }^{8}$ Structural violence is the notion that harm can be inflicted on individuals indirectly by a social, economic and political repressive system under which they live and which perpetuates discrimination, ${ }^{9}$ and which in this case targeted the poor to provide training material for the medical elite, thus affecting the impoverished in death. ${ }^{10}$

In continental Europe, skeletal reference collections are often comprised of individuals who have been disinterred from temporary burials in secularised municipal cemeteries - a common practice in Catholic and Orthodox countries. In these countries, perpetual mausoleums, rather than perpetual burials, are also common and are used by families to inter their loved ones. However, these tend to be more accessible to the better-off segments of society. Unclaimed remains are removed from temporary graves after they have skeletonised and are stored individually for a number of years in secondary plots, cremated, or re-interred in communal graves or ossuaries. ${ }^{11}$ In Portugal, for example, most graves in urban cemeteries are temporary and for periodical reuse. ${ }^{12}$ At the end of a three- to five-year term, temporary graves are opened and, if skeletonisation is complete, the remains are exhumed and placed in secondary, above-ground interments called 'ossários. ${ }^{13}$ These secondary interments can also be temporary and have terms of various lengths, varying from one to fifty years, and are priced correspondingly. Ossuaries' concessions can be renewed at their term. However, if they are not renewed for a fee, the remains are deemed unclaimed and are removed from their secondary interments and stored while awaiting cremation. Cemeteries also have perpetual plots and perpetual ossuaries, and thus remains interred in these are never incorporated into collections. This process would suggest that wealthier or better-off families are able to purchase perpetual plots and/or to pay rent to hold the remains in the secondary interments for a longer time after exhumation.

Since cemetery-based collections incorporate unclaimed remains, it is possible to assume that the process of collecting represents a similar process of exploiting the poor and underprivileged as in North American cadaver-derived collections. Some individuals are incorporated into cemetery-based collections when fees for secondary temporary concessions are not paid to the cemetery, or when families are unable to purchase secondary permanent plots, leading to the suggestion that they became unclaimed because families could not afford these costs. For example, 
Alves-Cardoso ${ }^{14}$ voiced these concerns in a 2015 conference paper but does not explore them further. While these can, hopefully, be further examined, the fact is that remains can be unclaimed due to a variety of reasons, namely lack of family members in general in the area, or an extended period since death and consequent loss of memory and family ties. The transition from exhumation from graves to deposition in secondary interments and to reburial in communal graves is by no means always immediate. After temporary secondary interments reach their term, relatives are notified to renew the concessions in order to prevent removal of skeletons from their individual secondary plots. If families fail to renew the concessions after several notifications, the cemetery often takes several years to clear human remains from their secondary interments or storage before they are disposed of through mass reburial or cremation.

North American collections derived from cadavers used for anatomical instruction have their origin in a late nineteenth-century context where grave robbing was the primary or only source of cadavers for anatomical instruction. ${ }^{15}$ Although the individuals included in anatomical skeletal collections were never buried, the socially and politically sanctioned system targeting the poor and impoverished that was established during the grave-robbing period persisted well into the twentieth century. ${ }^{16}$ Similar issues affected the sourcing of cadavers for anatomical instruction in England and continental Europe. ${ }^{17}$ In contrast, skeletal collections that incorporate unclaimed remains from cemeteries do not include individuals that were a source of cadavers for anatomical instruction. Unclaimed individuals were included in both anatomical ${ }^{18}$ and cemetery-derived collections, ${ }^{19}$ but the socio-political, historical and legal context varied considerably among the source populations. $^{20}$

Unclaimed remains at these European cemeteries are not the same as unclaimed bodies in a morgue, as they have already been given a primary burial as well as funerary rites by relatives. In fact, using the example of Portugal again, unclaimed remains are usually retained at the cemeteries for a number of years, allowing a significant amount of time for families to claim them before they are reburied in a communal grave or cremated. Disinterred remains from cemeteries will otherwise be disposed of if they were not collected for incorporation into an identified skeletal collection. Museums and other institutions acquire the remains, and the records that are so integral to human skeletal researchers, just before the skeletons are either relocated to an anonymous communal grave or cremated. ${ }^{21}$

Documentary information and historical context for cemetery-based collections provide the means to test whether these collections are derived from impoverished and underprivileged segments of the society, like the anatomy-based collections described above. This test can be carried out by contrasting the SES of individuals - as measured by occupation - with the length of time individuals remained in the cemetery before abandonment or the time elapsed between death and the incorporation of a skeleton into a collection. This time is a measure of how soon they are abandoned by their relatives or deemed unclaimed by the cemetery authorities. If cemetery collections are in fact incorporating most of these impoverished individuals, then there are a series of expectations: (1) time elapsed between exhumation 
from a temporary grave and incorporation in a collection should be very short for the majority of the individuals in that collection; (2) most individuals should be of low or very low SES; and (3) those individuals who are abandoned very soon after exhumation are likely to be of lower SES, whereas those abandoned very late after exhumation are likely to be of higher SES. It would be expected that remains of individuals of lower SES would be abandoned after shorter periods of time than those of higher SES because the families of higher-status individuals would be able to afford longer periods in secondary interments ${ }^{22}$ before they are deemed unclaimed. Higher-status individuals would achieve this by either being able to afford longer ossuary leases or renewing shorter leases for longer periods.

This study examines the relationship between SES and length of time individuals remained in the cemetery before abandonment and incorporation into a modern, identified skeletal collection from Lisbon, Portugal. ${ }^{23}$ By addressing this issue, one of our main goals is to better understand the social and cultural factors that affect ethical considerations about the disturbance of the recent dead in Europe, particularly concerns raised about the nature of identified skeletal reference collections in Portugal. The country has one of the largest number of these collections in Europe, sourced from unclaimed remains in modern cemeteries. Several of these collections sample a range of dates of death with a large span of time $(\sim 150$ years $)$ elapsed between death and incorporation of the skeletons into the collection, ${ }^{24}$ whereas others have targeted a narrow range of years of death $(\sim 20$ years $)$ and individuals who have been recently unclaimed. ${ }^{25}$ By examining the association between SES and time elapsed since death, and also historical documentary information about cemetery practices, this article will test the assumption that the unclaimed are largely comprised of the poor and underprivileged in Portuguese society in the Lisbon collection, in an attempt to address the concerns raised by Alves-Cardoso. ${ }^{26} \mathrm{~A}$ second goal of this article is to provide a framework to examine how SES is influencing the composition of other Portuguese and non-Portuguese cemetery-based skeletal reference collections, which is critical to future research. Framed under current ethical considerations about similar collections in Europe and North America, ${ }^{27}$ this study will provide some insight into the nature of cemetery-based identified skeletal reference collections and a new perspective on ethical issues that surround their creation, study and long-term curation.

\section{Materials and methods}

\section{Materials}

Data for this study consist of biographic information for a sample of individuals from the Lisbon reference skeletal collection who were buried in the cemeteries of the city of Lisbon between the 1890 s and the 1980 s. $^{28}$ Most of the individuals were buried in the Alto de São João, Benfica, and Prazeres cemeteries, with a smaller number buried in the cemeteries of Ajuda, and Lumiar. Most of this collection of complete, identified skeletons was amassed between the late 1980s and 1991 by Luis Lopes, an instructor of anthropology at the University of Lisbon and later full-time museum technician and curator at the National Museum of Natural 
History, where the collection is curated. The collection was later expanded by Hugo Cardoso between 2001 and 2004. ${ }^{29}$

We analysed biographic data including date of death, age at death, sex, cause of death, date of incorporation into the skeletal collection and occupation at the time of death from 333 adult females (21 to 101 years of age), 270 adult males (20 to 88 years of age) and 98 children (under 20 years of age) - a total of 701 individuals. Biographic information was retrieved from the Lisbon collection's database, which was compiled from cemetery records. These records are transcriptions of the information listed in the death certificate and/or civil registration of death. In the case of children, information about occupation refers to the listed occupation of the father at the time of death. Although some older children had an occupation at the time of death, the occupation of the father was considered a more reliable source of information about SES. ${ }^{30}$ Individuals for which at least one piece of information from this list was not available were excluded from the study. The sample consists of individuals from a range of socio-economic categories, since it includes those buried in almost all the municipal cemeteries in Lisbon including Ajuda, Lumiar, Alto de São João and Benfica, the last two being the largest cemeteries, and all four serving a largely working-class population. The Prazeres cemetery was available to a wealthier portion of the Lisbon society. While Prazeres and the remaining cemeteries served two broadly different segments of the population, this study focuses exclusively on the temporary graves, where a largely middle to low SES population was buried, regardless of where they were living. As a consequence, our sample includes a much larger proportion of individuals buried in Ajuda, Lumiar, Alto de São João and Benfica $(\mathrm{n}=682)$, as compared to Prazeres $(\mathrm{n}=19)$.

\section{Methods}

Adult males $(\mathrm{n}=270)$ were classified into SES groups using the documented occupation at the time of death. These socio-economic groups were devised according to the 1951 Registrar General's classification of occupations provided by Armstrong's ${ }^{31}$ and Cardoso's ${ }^{32}$ work, which translated this scheme to the Portuguese context using historical information. We devised two classification systems based on occupations as per Armstrong and Cardoso. ${ }^{33}$ The first system separates occupations into NonManual, Manual Skilled and Manual Unskilled occupations, which are converted into High, Middle and Low SES groups, respectively. The second system separates occupation into only Non-Manual and Manual, which converts to High and Low SES groups, respectively. Although imperfect, this approach is meant to reflect the SES disparities within the sample only, rather than attempting to extrapolate these classifications/stratifications to the early twentieth-century Lisbon society as a whole. Analysis was also conducted separately, using both systems of classification, on a sample of 211 males whose occupations were considered socio-economically ambiguous. These occupations included members of the police force, commercial employees, low-ranking army personnel and a variety of unspecific civil service occupations. Adult females $(n=333)$ were not classified into SES groups because of the ambiguous nature of the documented occupations. Over 95 per cent of the females are listed as 'doméstica', which is understood very broadly in Portuguese to 
mean housewife, stay-at-home mother, house cleaner or other occupation within the home. Although a socio-economic analysis of the females was not possible, an examination of sex differences in age or time elapsed since death was still carried out as a contrast to that of the male sample. Allocation of children $(n=98)$ to an SES group was based on the documented occupation of the father at the time of their death. The children were analysed using the same two-group and three-group systems for SES devised for the males.

For all individuals in the sample, date of death was subtracted from date of incorporation into the collection in order to obtain the length of time individuals remained at the cemetery prior to being added into the collection. Analysis of Variance (ANOVA) was used to examine whether there were significant differences in time elapsed in the cemetery before incorporation into the collection as well as age at death between Low/Middle/High and Low/High SES groups in both the male adult and child samples. These comparisons examined if SES affected the length of time individuals remained in the cemetery before being incorporated into the collection or the age at which individuals died. Box plots were used to illustrate the distribution of time elapsed in the cemetery before incorporation into the collection for the different socio-economic groups. This analysis was restricted to the adult male and child samples. Correlation analysis was performed with Pearson's coefficient to test the association between time elapsed and age at death in both male and female adult, and child samples. This analysis examined whether there is a relationship between the ages at which individuals died and how long they remained in the cemetery before abandonment. This relationship was illustrated by plotting time elapsed in years against age at death.

\section{Results}

The sample size, mean and standard deviation for time elapsed in a cemetery prior to abandonment for all males, selected males ${ }^{34}$ and children are presented in Table 1 for the two-group socio-economic classification system, and in Table 2 for the threegroup system. Females, whose SES could not be assessed from occupation, are presented in separate columns in both Tables 1 and 2. Mean time elapsed since death is slightly longer for the low SES groups in males, and the reverse in the children. ANOVA results for the comparison between the socio-economic groups are reported in Tables 1 and 2 and reveal no statistically significant differences between the two socio-economic groups for time elapsed between death and incorporation into the collection for all males, the selected dataset of males or children.

The sample size, mean and standard deviation for age at death for two-group and three-group occupational categories, respectively, and for the complete and selected male dataset as well as for the females and children are presented in Tables 3 and 4 . The results of the statistical analysis presented in Tables 3 and 4, demonstrate that males classified in the low SES groups died at a younger age, and differences are statistically significant. Children died at a relatively later age in the low SES group but differences in age at death of children between the socio-economic groups were not statistically significant. Results for the selected male dataset are similar to 
Table 1 Summary statistics for time elapsed between death and incorporation into the collection (in years) for the two socio-economic categories (High and Low)

\begin{tabular}{|c|c|c|c|c|c|c|c|c|c|c|c|}
\hline & \multicolumn{3}{|c|}{ Total } & \multicolumn{3}{|c|}{ High SES } & \multicolumn{3}{|c|}{ Low SES } & \multicolumn{2}{|c|}{ ANOVA } \\
\hline & $n$ & $\bar{x}$ & $s d$ & $n$ & $\bar{x}$ & $s d$ & $n$ & $\bar{x}$ & $s d$ & $F$ & $p$ \\
\hline Females* & 333 & 45.6 & 12.25 & - & - & - & - & - & - & - & - \\
\hline $\begin{array}{l}\text { Males (complete } \\
\text { dataset) }\end{array}$ & 270 & 47.1 & 13.0 & 124 & 45.7 & 11.98 & 146 & 48.3 & 13.66 & 2.67 & 0.104 \\
\hline $\begin{array}{l}\text { Males (selected } \\
\text { dataset) }\end{array}$ & 211 & 46.6 & 12.2 & 95 & 45.9 & 13.09 & 116 & 47.7 & 12.88 & 1.03 & 0.313 \\
\hline Children & 98 & 47.4 & 12.9 & 15 & 48.7 & 9.88 & 83 & 47.2 & 13.45 & 0.16 & 0.689 \\
\hline
\end{tabular}

${ }^{*}$ Descriptive statistics were calculated only for entire sample (see text).

Table 2 Summary statistics for time elapsed between death and incorporation into the collection (in years) for the three socio-economic categories (High, Middle and Low)

\begin{tabular}{|c|c|c|c|c|c|c|c|c|c|c|c|c|c|c|}
\hline & \multicolumn{3}{|c|}{ Total } & \multicolumn{3}{|c|}{ High SES } & \multicolumn{3}{|c|}{ Middle SES } & \multicolumn{3}{|c|}{ Low SES } & \multicolumn{2}{|c|}{ ANOVA } \\
\hline & $n$ & $\bar{x}$ & $s d$ & $n$ & $\bar{x}$ & $s d$ & $n$ & $\bar{x}$ & $s d$ & $n$ & $\bar{x}$ & $s d$ & $F$ & $p$ \\
\hline Females* & 333 & 45.6 & 12.25 & - & - & - & - & - & - & - & - & - & - & - \\
\hline $\begin{array}{l}\text { Males (complete } \\
\text { dataset) }\end{array}$ & 270 & 47.1 & 13.0 & 124 & 45.7 & 11.98 & 55 & 47.9 & 12.27 & 91 & 48.5 & 14.49 & 1.37 & 0.257 \\
\hline $\begin{array}{l}\text { Males (selected } \\
\text { dataset) }\end{array}$ & 211 & 46.6 & 12.2 & 95 & 45.9 & 13.09 & 57 & 47.7 & 12.18 & 60 & 47.7 & 13.62 & 0.51 & 0.601 \\
\hline Children & 98 & 47.4 & 12.9 & 15 & 48.7 & 9.88 & 37 & 47.8 & 13.29 & 46 & 46.7 & 13.85 & 0.16 & 0.854 \\
\hline
\end{tabular}

* Descriptive statistics were calculated only for entire sample (see text).

Table 3 Summary statistics for age at death (in years) for the two socio-economic categories (High and Low)

\begin{tabular}{|c|c|c|c|c|c|c|c|c|c|c|c|}
\hline & \multicolumn{3}{|c|}{ Total } & \multicolumn{3}{|c|}{ High SES } & \multicolumn{3}{|c|}{ Low SES } & \multicolumn{2}{|c|}{ ANOVA } \\
\hline & $n$ & $\bar{x}$ & $s d$ & $n$ & $\bar{x}$ & $s d$ & $n$ & $\bar{x}$ & $s d$ & $F$ & $p$ \\
\hline Females* & 333 & 65.2 & 18.9 & - & - & - & - & - & - & - & - \\
\hline $\begin{array}{l}\text { Males (complete } \\
\text { dataset) }\end{array}$ & 270 & 57.3 & 18.0 & 124 & 60.2 & 18.05 & 146 & 54.9 & 17.60 & 6.15 & 0.014 \\
\hline $\begin{array}{l}\text { Males (selected } \\
\text { dataset) }\end{array}$ & 211 & 57.2 & 18.1 & 95 & 59.5 & 18.99 & 116 & 55.3 & 17.02 & 2.96 & 0.087 \\
\hline Children & 98 & 8.5 & 6.4 & 15 & 6.7 & 7.20 & 83 & 8.8 & 6.18 & 1.38 & 0.244 \\
\hline
\end{tabular}

${ }^{*}$ Descriptive statistics were calculated only for entire sample (see text).

the complete dataset, but the differences are not statistically significant, although marginally at the 0.05 and 0.10 level.

The box plots demonstrate almost total overlap in the distribution of time elapsed between occupation groups for time elapsed for both two-group (Figure 1) and three-group (Figure 2) socio-economic categories in males. The box plots for the children demonstrate the same pattern as the males (Figures 3 and 4). These results confirm that SES had no effect on the length of time an individual remained in the cemetery before being abandoned and incorporated into the collection. 


\section{Greer Vanderbyl et al.}

Table 4 Summary statistics for age at death (years) for the three socio-economic categories (High, Middle and Low)

\begin{tabular}{|c|c|c|c|c|c|c|c|c|c|c|c|c|c|c|}
\hline & \multicolumn{3}{|c|}{ Total } & \multicolumn{3}{|c|}{ High SES } & \multicolumn{3}{|c|}{ Middle SES } & \multicolumn{3}{|c|}{ Low SES } & \multicolumn{2}{|c|}{ ANOVA } \\
\hline & $n$ & $\bar{x}$ & $s d$ & $n$ & $\bar{x}$ & $s d$ & $n$ & $\bar{x}$ & $s d$ & $n$ & $\bar{x}$ & $s d$ & $F$ & $p$ \\
\hline Females* & 333 & 65.2 & 18.9 & - & - & - & - & - & - & - & - & - & - & - \\
\hline $\begin{array}{l}\text { Males (complete } \\
\text { dataset) }\end{array}$ & 270 & 57.3 & 18.0 & 124 & 60.2 & 18.05 & 55 & 59.1 & 17.93 & 91 & 53.9 & 17.43 & 3.45 & 0.033 \\
\hline $\begin{array}{l}\text { Males (selected } \\
\text { dataset) }\end{array}$ & 211 & 57.2 & 18.1 & 95 & 59.5 & 18.99 & 57 & 56.7 & 17.69 & 60 & 53.9 & 16.38 & 1.83 & 0.163 \\
\hline Children & 98 & 8.5 & 6.4 & 15 & 6.7 & 7.20 & 37 & 8.9 & 6.53 & 46 & 8.7 & 5.95 & 0.69 & 0.503 \\
\hline
\end{tabular}

*Descriptive statistics were calculated only for entire sample (see text).

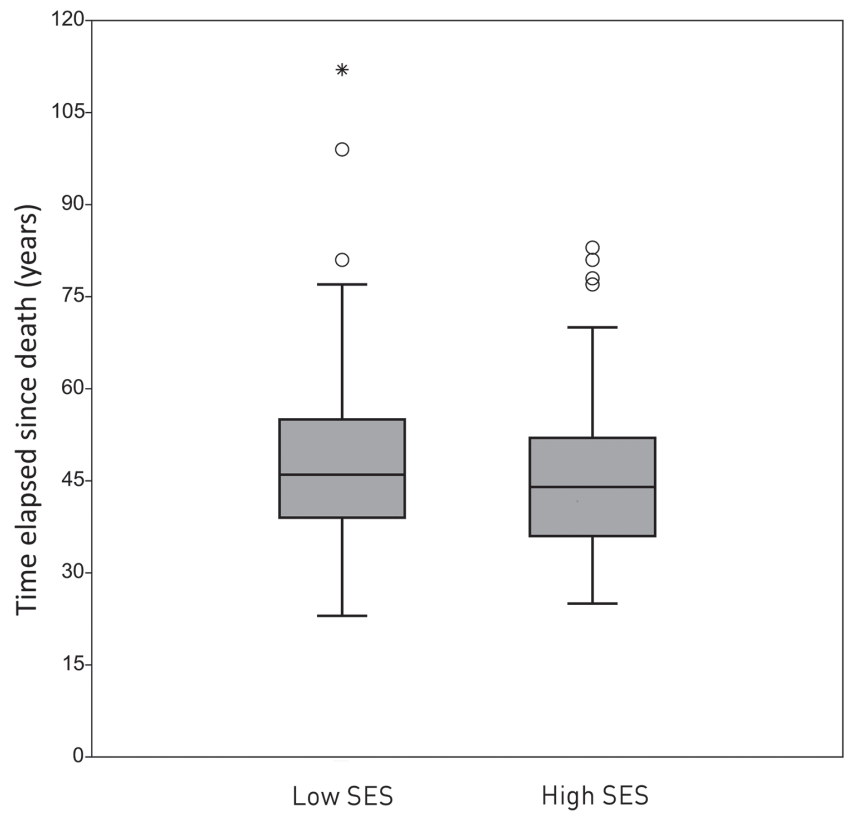

Figure 1 Box plots of the distribution of time elapsed between death and incorporation into the collection (years) in the complete male dataset and for two SES groups (low and high). The box includes the interquartile range ( 25 per cent to 75 per cent of the distribution), the centre line represents the median, and the dots are outliers.

Correlation results reveal a slight significant and negative $(\mathrm{r}=-0.162, \mathrm{p}=$ 0.007) association between time elapsed since death and age at death for the male complete dataset, and a similar negative $(\mathrm{r}=-0.182)$ and significant $(\mathrm{p}=0.001)$ association for the females. This suggests that the older an individual was at the 


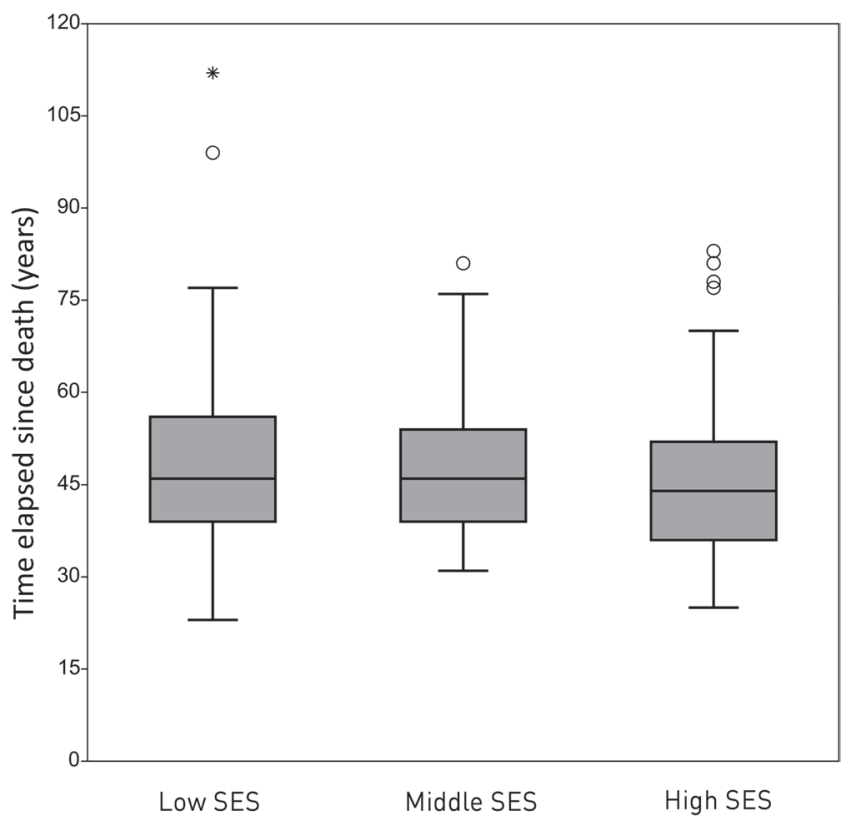

Figure 2 Box plots of the distribution of time elapsed between death and incorporation into the collection (years) in the complete male dataset and for three SES groups (low, middle and high). The box includes the interquartile range ( 25 per cent to 75 per cent of the distribution), the centre line represents the median and the dots are outliers.

time of their death, the shorter amount of time they remained in secondary burial plots before abandonment. No correlation is apparent in the child data $(r=0.007$, $\mathrm{p}=0.948$ ). Age at death plotted against time elapsed shows that older individuals tend to be abandoned after shorter lengths of time for all occupation groups in the male (Figure 5) and female (Figure 6) samples, though no such pattern exists for the child sample (Figure 7).

\section{Discussion}

Our results show that the majority of skeletons in the sample were incorporated into the collection forty to sixty years after death, with very few being included in the collection less than thirty years after death. These results are not consistent with the expectation that very short periods elapsed after exhumation and incorporation for individuals of low SES. We instead suggest that older adult individuals are likely to be abandoned after a shorter amount of time than younger adult individuals, regardless of SES. Adults who died at a younger age were more likely to have younger surviving family members who could care for the graves of the deceased for longer periods. 


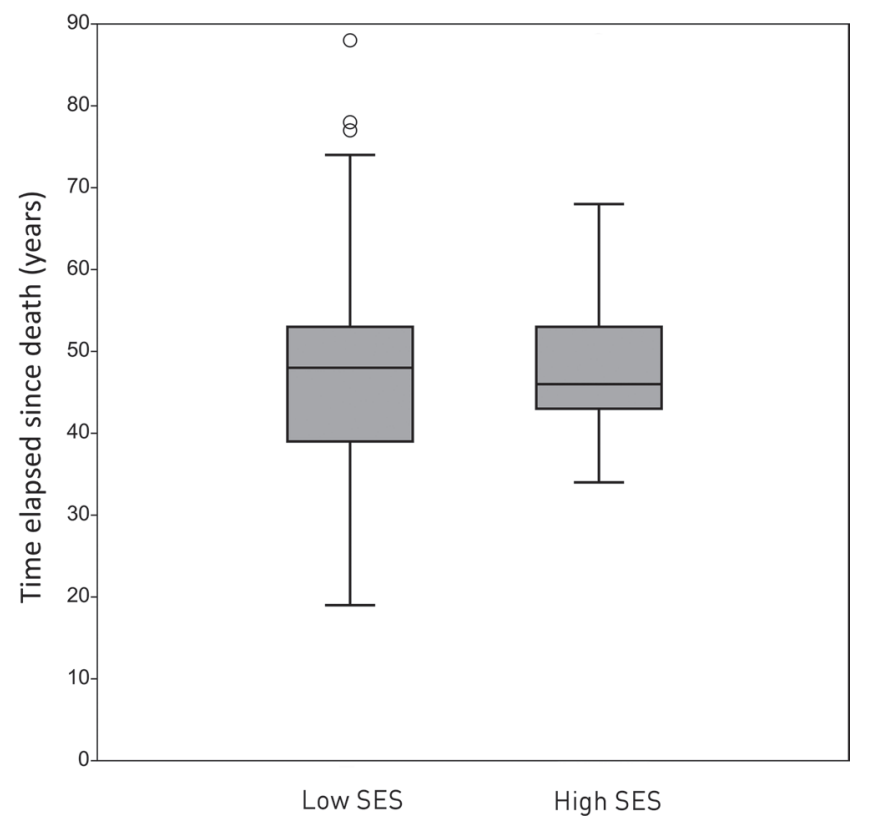

Figure 3 Box plots of the distribution of time elapsed between death and incorporation into the collection (years) in the child sample for two SES groups (low and high). The box includes the interquartile range ( 25 per cent to 75 per cent of the distribution), the centre line represents the median and the dots are outliers.

For adults who died at an older age, the opposite is true and, as such, their remains are abandoned after shorter periods. This trend is not affected by SES. Although the remains of children are, on average, abandoned at about the same time as the remains of adult individuals, children show no relationship between age at death and time elapsed since death. Consequently, the analysis reveals no association between SES and time elapsed before abandonment in our sample of the Lisbon collection. This suggests that being of lower SES did not result in an individual being abandoned after a shorter period than higher-status individuals, as was the expectation being tested. If the collection process targeted lower-status individuals, then higherstatus individuals would have remained in the cemetery for significantly longer than those of lower SES, which is not consistent with our results.

In addition to the amassing of skeletons not targeting the low SES individuals, historical data show that the collection process actually excludes the poor and marginalised citizens of Lisbon. For most of the nineteenth and twentieth centuries, the indigent, marginalised and extremely poor were not given individual graves and were, instead, buried directly in a communal grave. ${ }^{35}$ (Even if they were given temporary burials, the remains of these individuals would be disinterred at the 


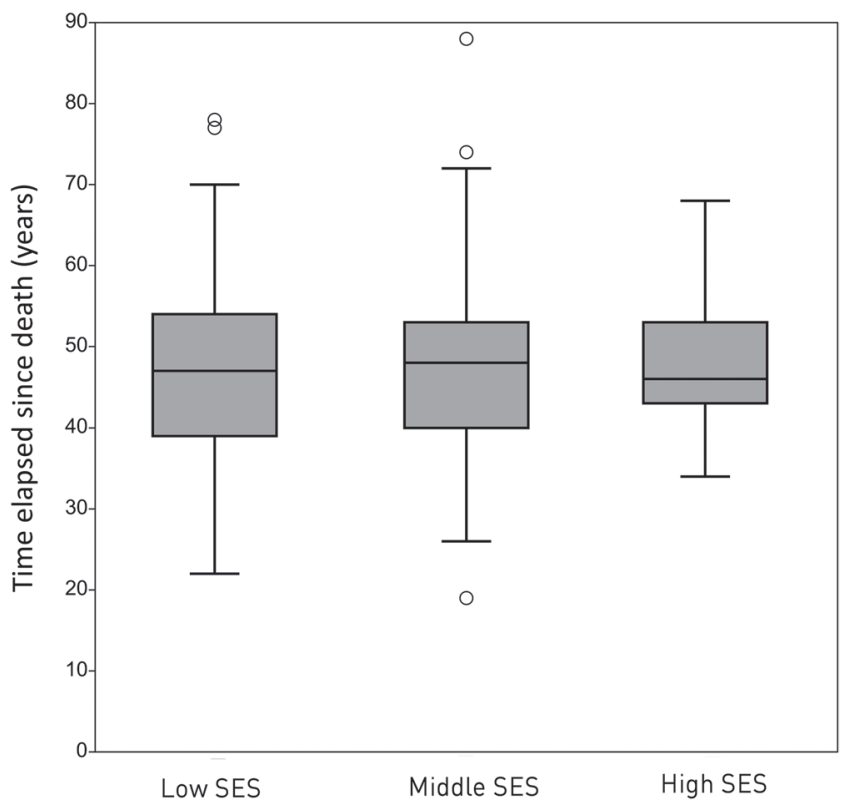

Figure 4 Box plots of the distributions of time elapsed between death and incorporation into the collection (years) in the child sample for three SES groups (low, middle and high). The box includes the interquartile range (25 per cent to 75 per cent of the distribution), the centre line represents the median and the dots are outliers.

end of the three- to five-year term and reburied in the communal grave. Because unclaimed secondary interments are the source of human remains for the collection, these marginalised and poor individuals were never available for inclusion. If the very poor or marginalised were predominant in the collection, a high frequency of institutionalised deaths occurring in hospitals or shelters, or unattended deaths occurring among the homeless resulting in autopsy, would have been identified through the address at the time of death, though that was not the case. In the study sample, while twenty-one individuals died in the hospital, many of these were of non-manual, high SES occupation, therefore hospital deaths may not be related to institutionalisation or marginalisation. There were also eleven cases in the collection where the individual was autopsied, but there is no indication that these were unattended deaths associated with homelessness. Only one individual died in a poor-relief shelter.

While any skeletal collection does not necessarily represent the population from which it was derived, it is possible to use historical data to provide context for who was included in a collection and what variation was sampled. ${ }^{36}$ This study provides evidence that the collection process did not directly target those of the lowest SES 


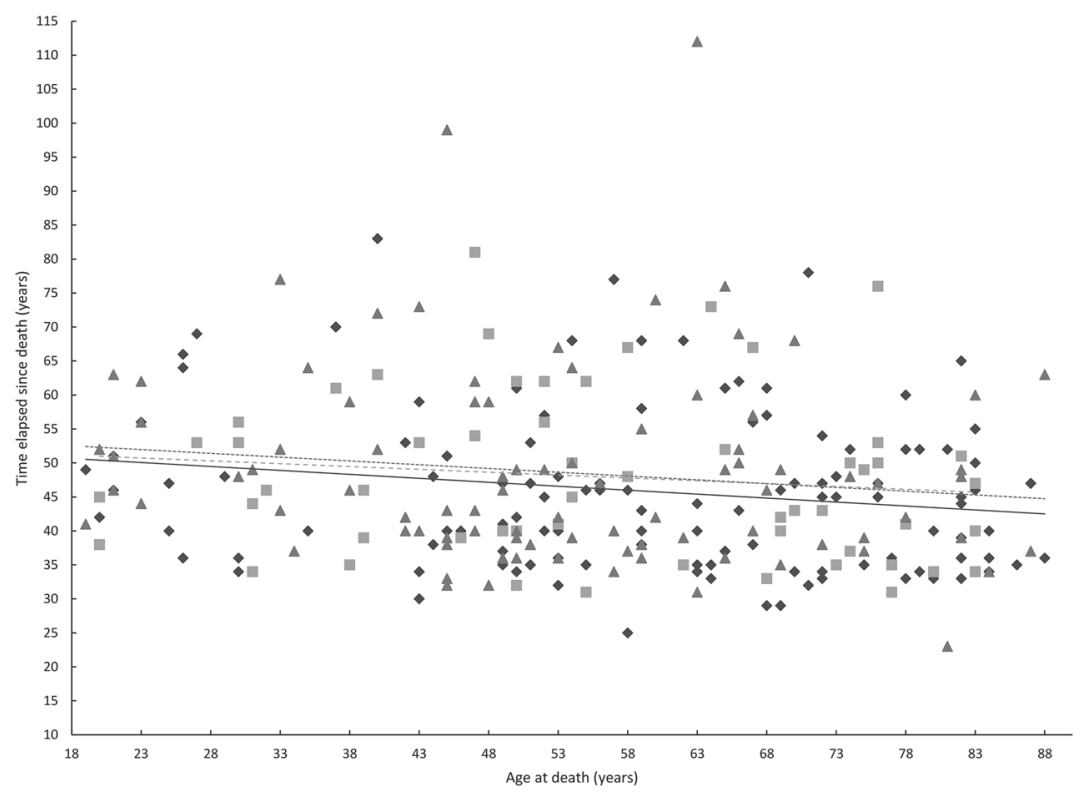

Figure 5 Scatterplot of time elapsed (years) by age at death (years) for the complete male dataset $(n=270)$ showing a trend in all SES groups towards older individuals being abandoned after shorter lengths of time (High SES: diamonds, solid line; Middle SES: squares, dashed line; Low SES: triangles, dotted line).

group in our sample but, rather, a sample of mostly low- to middle-class individuals who were eventually abandoned after long periods of time in a cemetery. The study sample contains remains of a diverse group of both lower- and middle-class individuals who lived in one of the few urban centres in Portugal during the early to middle twentieth century. It includes a very diverse group of individuals ranging from low SES, such as day labourers, to much higher-status individuals such as lawyers, tax inspectors or notaries. The period of the collection follows the creation of public cemeteries in Portugal during the mid- to late nineteenth century, during which time people became increasingly detached from cemeteries ${ }^{37}$ Xisto, ${ }^{38}$ for example, describes the duty to maintain graves or ossuaries as being time cumbersome for families, this being one of the main reasons why the ties are lost and relatives stop visiting cemeteries and attending graves. With perhaps the exception of the very wealthy, most graves and secondary burial plots will eventually be deemed abandoned. In 2011, for example, 60 per cent of exhumations resulted in abandonment of remains, which is seen as a strong disassociation between the deceased and their kin. ${ }^{39}$ These issues are common in the cemeteries of major Portuguese cities, due to issues of migration, social isolation and relaxation or loss of religious norms and traditions. 


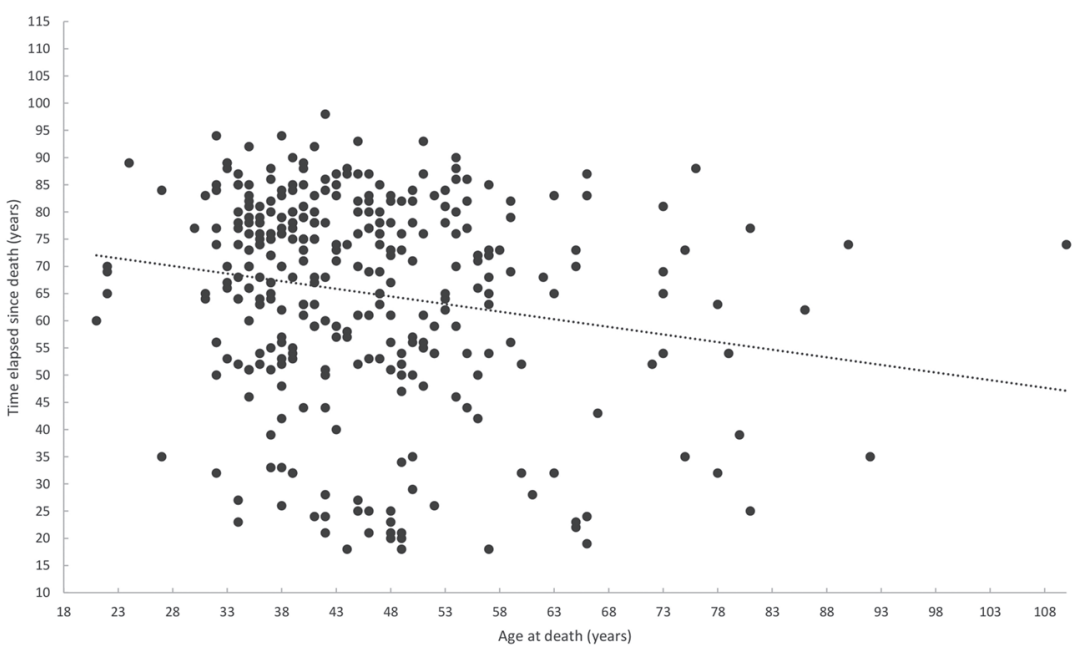

Figure 6 Scatterplot of time elapsed (years) by age at death (years) for the female dataset $(n=333)$ showing a trend in all SES groups towards older individuals being abandoned after shorter lengths of time.

In this secular cemetery system, wealthy people could afford perpetual graves, whereas others would likely be transferred to the communal grave immediately after exhumation, with no secondary interments as they were too expensive. ${ }^{40}$ In many cases earlier in the twentieth century, people were buried directly in the communal grave. ${ }^{41}$ This means that the sample, and collection as a whole, derived from a low to middle socio-economic section of the population who could afford temporary and secondary burial, but not perpetual graves. This is not to say that all wealthy or better-off people were buried in perpetuity and all others had temporary graves. We can see, based on occupation, that some of the individuals in the sample were of fairly high status for the time. Some wealthy people chose not to purchase perpetual graves, or perhaps had moved to an urban centre away from family, while, in contrast, some middle-class people did invest in perpetual family tombs. ${ }^{42}$

The collection studied for this project is the result of a system that excluded the extremely poor almost completely, as they were not given individualised, documented burials and therefore could not be incorporated into the collection. Temporary graves had a cost and ossuaries have to be rented, so the poor would not have been able to afford a proper primary individualised burial and also a secondary place of burial. The poorest would have been placed directly in the communal graves or moved there immediately after they were exhumed from a primary burial. Structural violence can then be said to be absent from the collection, as it excludes ${ }^{43}$ rather than includes ${ }^{44}$ the extremely poor and marginalised individuals. In addition, through burial practice the wealthy who could afford perpetual burial are also excluded 


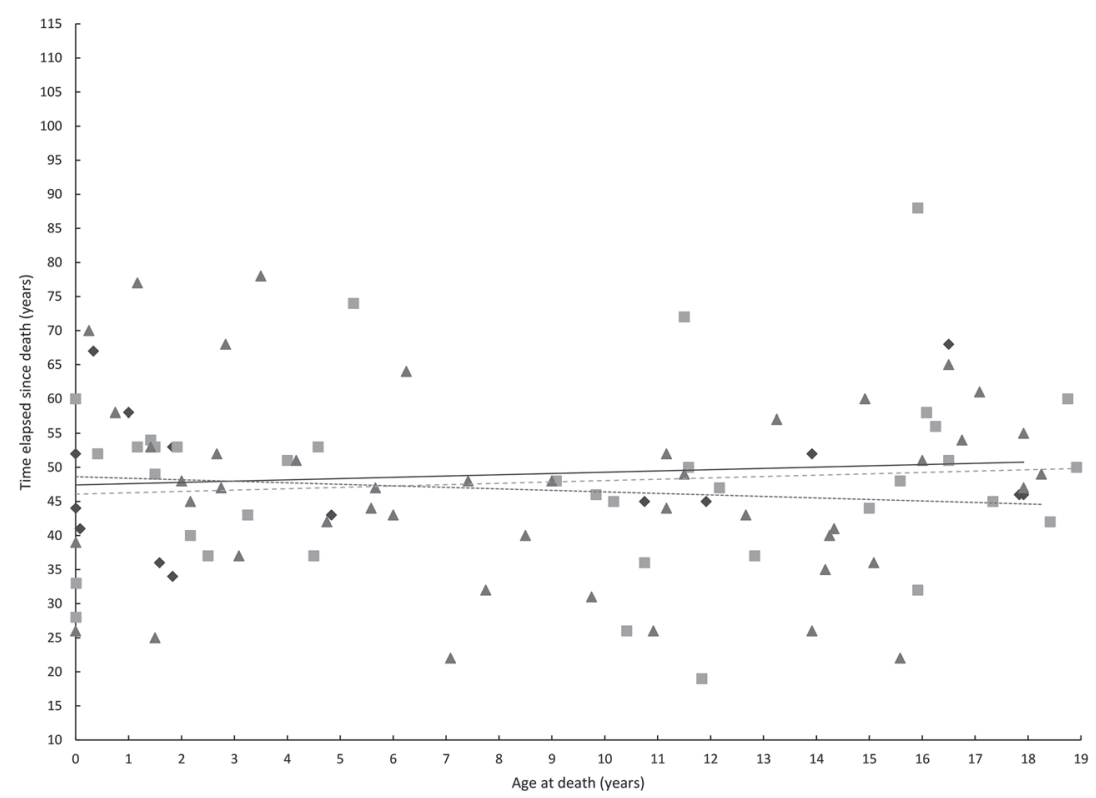

Figure 7 Scatterplot of time elapsed (years) by age at death (years) for the child dataset $(\mathrm{n}=98)$, showing no trend between age at death and time elapsed since death in all occupation groups (High SES: diamonds, solid line; Middle SES: squares, dashed line; Low SES: triangles, dotted line).

from the collection. However, structural violence can be said to be present in burial practices, but these do not impact on the collection process.

In continental Europe, disinterment and secondary burial in an ossuary or communal grave is a burial tradition regularly practised by the majority of the population. This practice has long been associated with the Catholic faith, though most cemeteries have been managed by secular entities since the end of the nineteenth century, when concerns about hygiene and public health led to the construction of new cemeteries and the adoption of Napoleonic laws concerning the management of cemeteries. ${ }^{45}$ Ossuaries were originally used as secondary burials to keep remains within the churchyard and close to prayers, while simultaneously dealing with overcrowding, ${ }^{46}$ and they are now used to maintain the individuality of the deceased. Disinterment can be a result either of a predetermined length of elapsed time or of the need to create space for a new burial, depending on the organisation of the cemetery, grave space and whether a family has access to a space for a short, extended or infinite period of time. ${ }^{47}$ Most countries that practise secondary burials usually have legislation to ensure that a body is left in the ground or other place of primary interment for a certain length of time before it is disinterred, depending on the burial conditions. ${ }^{48}$ 
In contrast to continental Europe, cemetery collections do not exist in North America because of the colonial history of this region. In the UK and North America, cemeteries follow the traditionally Protestant practice and members of the Protestant faith do not disinter the remains of their dead unless under unusual circumstances. ${ }^{49}$ What began as a luxury that could be afforded only by the rich, perpetual interment eventually became the norm throughout Protestant Europe and North America. ${ }^{50}$ Even 'Catholic' cemeteries in North America follow the Protestant burial tradition of perpetuity: Catholic burial practices in the United States and Canada much more closely resemble those of the Protestant tradition, ${ }^{51}$ which Lee Decker $^{52}$ attributes to the largely British colonial presence in these regions. While disinterment was once common practice in England, it had virtually disappeared by the 1800s, and even the poorest who had been buried in communal graves were left there in perpetuity, despite the overcrowding issues as in the rest of Europe. ${ }^{53}$

The lack of relationship between abandonment and SES seems to hold true for the segment of the Lisbon collection that includes individuals who died between 1890 and 1980. However, it is important to note that a significant portion of the collection is currently still undocumented and includes a large proportion of individuals who have died more recently, around and after 1980. Other collections in Portugal incorporated individuals who died between 1969 and 2001, ${ }^{54}$ and even more recently between 1995 and 2008. ${ }^{55}$ Likewise, it would be interesting to examine whether the lack of association between time elapsed since death and SES found in this study is also found in these other collections, particularly because the communal graves in Portugal were decommissioned in $1962^{56}$ and, consequently, the poorest began to be systematically buried in temporary plots after that date. In contrast, older collections, such as the Coleção de Esqueletos Identificados (CEI) in Coimbra, ${ }^{57}$ which includes individuals who died between 1904 and 1938, are unlikely to have sampled the poorest segments of the society, similarly to our sample from the Lisbon collection.

The period during which the majority of individuals in these earlier collections - Lisbon and CEI in Coimbra - lived and died encompasses the time during which Portugal was under significant political and social unrest and subsequent dictatorship. This was a time of great social inequality, government instability and economic uncertainty. There were several coups between 1910 and 1926, and a brief civil war followed by the Estado Novo dictatorship from 1933 to 1974, the longest European dictatorship. ${ }^{58}$ Furthermore, colonial wars in Africa served only to exacerbate the socio-economic and political problems. During the earlier years of this period there really was no traditional 'middle class', as the society was considered a two-class system with a large base of peasants and a small elite class that owned most of the land and controlled the wealth. ${ }^{59}$ The emerging middle class in the late nineteenth century was restricted to urban centres. This new middle class was more a part of the upper class, while the peasantry and working class remained repressed. During this period, Portugal emerged from the nineteenth century as a declining world political power with a declining monarchy, fragile agricultural systems, incomplete industrialisation, weak capitalism and a centralised, strong, Catholic church. Because of this, the country had some of the lowest incomes per capita in Europe, poor living 
conditions, high infant mortality and deep social problems. ${ }^{60}$ This evidence for structural violence acting on the Portuguese population of the time only indirectly affects the socio-economic composition of the Lisbon collection.

Generally, the process of amassing cemetery-derived collections does suggest that these collections sample a broader cross-section of the population because of the widespread use of temporary burial plots in cemeteries. ${ }^{61}$ In comparison, a very large majority of the identified human skeletal collections in North America resulted from the rendering of bodies used for anatomical instruction at medical schools throughout the United States. ${ }^{62}$ Because of these origins, North American collections are not so representative of living populations as are their European counterparts. Children and women generally are greatly underrepresented in North American collections, which has been attributed, in part, to the disproportionate number of males that made up the populations exploited for cadavers: the poor, immigrants, criminals and transients who went unclaimed in death. ${ }^{63}$ An unclaimed, dissected and rendered body in a collection should not be viewed in the same light as an unclaimed skeleton exhumed from a cemetery or removed from and ossuary, as the circumstances that led to their incorporation into an identified skeletal collection are vastly different.

Our focus on occupation as the single source of information about SES is not without problems, and concerns can be raised as to, for example, the categorisation of extinct occupations or whether the occupation at the time of death accurately represents life-long status. ${ }^{64}$ The individual's address at the time of death - which is available for most individuals in the collection - could have been tentatively used to support the SES classification used here. While an SES classification based on address was completed in another study using the same collection, ${ }^{65}$ it was restricted to the children, and a new classification for the adults would have to be devised for this study. Because of the complexity of such classification ${ }^{66}$ we chose to focus exclusively on occupation. Although we did not attempt to develop this classification, it is clear from the collection records that there was a diversity in where the homes of individuals in collections were located, from working-class neighbourhoods to higher-status areas. On the other hand, given that there was a good match between the SES classification based on occupation and address in Cardoso (2005), it seems unlikely that our results would be significantly different. However, such an assumption should not deter further analysis on this subject.

In addition to some of the social issues explored in this article, this research provides a framework for exploring how documentary data and a good understanding of the history of a collection are important for a more nuanced approach to assessing the complexity of variation sampled in that collection. Rather, in order to provide context for skeletal data collection, it is necessary to consider documentary information, including the protocol for inclusion in a collection. Despite some superficial similarities among cemetery or anatomical collections, variation captured in all collections is inherently biased, but the nature and the magnitude of the bias varies by collection and the research question addressed. ${ }^{67}$ Furthermore, economic and social disparity had a direct impact on the process for inclusion in most anatomical collections but not on cemetery collections, or at least not in Portugal in the 
twentieth century. However, the skeletal manifestations of poverty vary considerably by collection. For example, the individuals in the Coimbra collection (Coimbra, Portugal) lived contemporaneously with the people who were eventually included in the Lisbon collection. As with the Lisbon collection, the Coimbra collection was derived from unclaimed bodies from a cemetery but did not necessarily target marginalised groups. In contrast, the Terry collection (USA), is an anatomical collection that does include a disproportionate number of disadvantaged individuals. ${ }^{68}$ When controlling for year of birth (secular changes), the growth of Coimbra collection males was so stunted that the mean femur length of males from the Coimbra collection is not significantly different than the female mean from the Terry collection. ${ }^{69}$ This discrepancy can be explained in part by the timing of inclusion in each collection. Although the years of birth and ages sampled in the Coimbra and Terry collections overlap, most of the individuals in the Terry collection died during the Great Depression. The magnitude of economic and social disparity at the end of life which led to inclusion in the collection was not the same as the magnitude during the growth and development period, when growth would have been compromised. Therefore, it is essential to assess documentary data and historical, socio-economic and political context for the living population and the skeletal collection derived from it in order to fully assess the source of the variation sampled in a given collection.

\section{Conclusions}

We examined a sample of the Lisbon skeletal reference collection with the goal of understanding the relationship between SES and incorporation into the collection by abandonment. Our data reveal that there is no relationship between the SES of an individual and the length of time they remained in a cemetery prior to abandonment, and subsequent inclusion in the collection. These results demonstrate that people of low SES who were incorporated into this collection were not abandoned after shorter periods than higher-status individuals, and thus more likely to be included in the collection. There seems to be no targeted selection of individuals of low SES when incorporating remains into the collection. Additionally, research into the background of the collection and about funerary practices in Portugal has shown that the extremely poor and most marginalised in society were excluded from the collection altogether due to cemetery practices that did not allow for inclusion in a research collection. Those individuals or families who could not afford individualised burials for any length of time were instead placed in large communal graves or eventually cremated. This pattern of inclusion is in contrast to North American cadaver-based collections that directly targeted the poor and marginalised in society. Structural violence in the United States that facilitated the accumulation of collections is not seen in the Lisbon collection, and structural violence seems to be absent due to the absence of the poorest and most marginalised from the collection. These findings will allow researchers to view cemetery-based collections as products of an entirely different process than cadaver-based collections. While cemeterybased collections may sample only a specific subset of an entire population, they 


\section{Greer Vanderbyl et al.}

are not necessarily comprised of the institutionalised poor and marginalised of the society.

\section{Acknowledgements}

This research was partly supported by the Natural Sciences and Engineering Research Council of Canada and a Simon Fraser University Vice-President Research Undergraduate Student Research Award (VPR-USRA).

\section{Notes}

1 J. Albanese, 'Strategies for Dealing with Bias in Identified Reference Collections and Implications for Research in the 21st Century', in C. Henderson and F. Alves Cardoso (eds), Identified Skeletal Collections: The Testing Ground of Anthropology (Oxford. Archaeopress, 2018), pp. 59-82; J. Albanese, 'A Metric Method for Sex Determination Using the Hipbone and Femur', Journal of Forensic Sciences, 48 (2003), 263-73; J. Albanese, A. Tuck, J. Gomes and H. F. V. Cardoso, 'An Alternative Approach for Estimating Stature from Long Bones that Is Not Population- or Group-Specific', Forensic Science International, 259 (2016), 59-68, DOI: 10.1016/j.forsciint.2015.12.011; H. F. V. Cardoso, 'Brief Communication: The Collection of Identified Human Skeletons Housed at the Bocage Museum (National Museum of Natural History), Lisbon, Portugal', American Journal of Physical Anthropology, 129:2 (2006), 173-6, DOI: 10.1002/ajpa.20228.

2 D. R. Hunt and J. Albanese, 'The History and Demographic Composition of the Robert J. Terry Anatomical Collection', American Journal of Physical Anthropology, 127 (2005), 406-17; R. W. Mann, 'Our Bones: The Need for Diverse Human Skeletal Collections', Anthropology, 1:2 (2013), DOI:10.4172/antp.1000e103; E. Weiss-Krejci, 'Excarnation, Evisceration, and Exhumation in Medieval and Post-Medieval Europe', in G. F. M. Rakita (ed.), Interacting with the Dead: Perspectives on Mortuary Archaeology for the New Millennium (Gainsville, University Press of Florida, 2005), pp. 155-72. C. Quigley, Skulls and Skeletons: Human Bone Collections and Accumulations (Jefferson, McFarland \& Company, Inc., 2001).

3 Albanese, 'Strategies for Dealing with Bias'; D. A. Komar and C. Grivas, 'Manufactured Populations: What Do Contemporary Reference Skeletal Collections Represent? A Comparative Study Using the Maxwell Museum Documented Collection', American Journal of Physical Anthropology, 137:2 (2008), 224-33, DOI: 10.1002/ajpa.20858.

4 Albanese, 'Strategies for Dealing with Bias'; R. Watkins and J. Muller, 'Repositioning the Cobb Human Archive: The Merger of a Skeletal Collection and its Texts', American Journal of Human Biology, 27:1 (2015), 41-50, DOI: 10.1002/ajhb.22650.

5 Albanese, 'Strategies for Dealing with Bias'; Komar and Grivas, 'Manufactured Populations'. 
6 Hunt and Albanese, 'The History and Demographic Composition of the Robert J. Terry Anatomical Collection'; Watkins and Muller, 'Repositioning the Cobb Human Archive'.

7 M. Trotter, 'Robert James Terry, 1871-1966', American Journal of Physical Anthropology, 56 (1981), 503-8. K. C. Nystrom, 'The Bioarchaeology of Structural Violence and Dissection in the 19th-Century United States: Structural Violence and Dissection', American Anthropologist, 116:4 (2014), 765-79, DOI:

10.1111/aman.12151. Albanese, 'Strategies for Dealing with Bias'; J. Albanese, 'The Grant Human Skeletal Collection and Other Contributions of J. C. B. Grant to Anatomy, Osteology, and Forensic Anthropology', in C. Henderson and F. Alves Cardoso (eds), Identified Skeletal Collections: The Testing Ground of Anthropology (Oxford, Archaeopress, 2018), pp. 35-57.

8 C. de La Cova, 'Cultural Patterns of Trauma Among 19th-Century-Born Males in Cadaver Collections', American Anthropologist, 112 (2010), 589-606. J. L. Muller, K. E. Pearlstein and C. de la Cova, 'Dissection and Documented Skeletal Collections: Embodiments of Legalized Inequality', in K. C. Nystrom (ed.), The Bioarchaeology of Dissection and Autopsy in the United States (Springer International Publishing, 2017), pp. 185-201. Nystrom, 'The Bioarchaeology of Structural Violence'; Watkins and Muller, 'Repositioning the Cobb Human Archive.'

9 P. Farmer, 'On Suffering and Structural Violence: A View from Below', Daedalus, 125:1 (1996), 261-83. P. Farmer, 'An Anthropology of Structural Violence', Current Anthropology, 45:3 (2004), 305-25.

10 de la Cova, 'Cultural Patterns of Trauma'; Muller et al. 'Dissection and Documented Skeletal Collections'; Nystrom, 'The Bioarchaeology of Structural Violence'; Watkins and Muller, 'Repositioning the Cobb Human Archive'.

11 I. Alemán, J. Irurita, A. R. Valencia, A. Martínez, S. López-Lázaro, J. Viciano and M. Botella, 'Brief Communication: The Granada Osteological Collection of Identified Infants and Young Children', American Journal of Physical Anthropology, 49:4 (2012), 606-10; M. G. Belcastro, B. Bonfiglioli, M. E. Pedrosi, M. Zuppello, V. Tanganelli and V. Mariotti, 'The History and Composition of the Identified Human Skeletal Collection of the Certosa Cemetery (Bologna, Italy, 19th-20th Century)', International Journal of Osteoarchaeology, 27 (2017), 912-25; C. Cattaneo, D. Mazzarelli, A. Cappella, E. Castoldi, M. Mattia, P. Poppa, D. De Angelis, A. Vitello and L. Biehler-Gomez, 'A Modern Documented Italian Identified Skeletal Collection of 2127 Skeletons: The CAL Milano Cemetery Skeletal Collection', Forensic Science International, 287 (2018), 219.e1-219.e5; C. Eliopoulos, A. Lagia and S. Manolis, 'A Modern, Documented Human Skeletal Collection from Greece, HOMO - Journal of Comparative Human Biology, 58:3 (2007), 221-8, DOI: 10.1016/j.jchb.2006.10.003; M. T. Ferreira, R. Vicente, D. Navega, D. Gonçalves, F. Curate and E. Cunha, 'A New Forensic Collection Housed at the University of Coimbra, Portugal: The 21st Century Identified Skeletal Collection', Forensic Science International, 245 (2014), 202.e1-202.e5; S. Ghosh, 'Human Cadaveric Dissection: A Historical Account from Ancient Greece to the Modern Era', Anatomy \& Cell Biology, 48:3 (2015), 153-69; C. Rissech and 
D. W. Steadman, 'The Demographic, Socio-Economic and Temporal Contextualisation of the Universitat Autònoma de Barcelona Collection of Identified Human Skeletons (UAB Collection)', International Journal of Osteoarchaeology, 21 (2011), 313-22.

12 Cardoso, 'The Collection of Identified Human Skeletons Housed at the Bocage Museum.

13 Ossuaries: locations created for the purpose of storing human skeletal remains such as a box, urn, chest, or structure.

14 F. Alves Cardoso, 'With Who's Permission? Using Human Skeletal Tissue to Build Identified Skeletal Collections'. Paper presented at the ASA14 Decennial Conference: Anthropology and Enlightenment, Edinburgh. 22 June 2015.

15 Albanese, 'Strategies for Dealing with Bias'.

16 Ibid. J. Breeden, 'Body snatchers and anatomy professors: medical education in 19th century Virginia, Virginia Magazine of History and Biography, 83 (1975), 321-45; J. M. Harrington and R. L. Blakely, Bones in the Basement: Postmortem Racism in Nineteenth-Century Medical Training (Washington, DC, Smithsonian Institution Press, 1997); A. M. Lassek, Human Dissection: Its Drama and Its Struggle. (Springfield, Charles C. Thomas, 1958). Muller et al. 'Dissection and Documented Skeletal Collections'; S. R. Wilf, 'Anatomy and Punishment in Late Eighteenth-Century New York', Journal of Society and History, 22 (1989), 507-30.

17 R. Richardson, Death, Dissection, and the Destitute (Chicago, IL, University of Chicago Press (2001).

18 Unclaimed individuals were unclaimed cadavers.

19 Unclaimed individuals were unclaimed skeletal remains.

20 Albanese, 'Strategies for Dealing with Bias'.

21 Cardoso, 'The Collection of Identified Human Skeletons Housed at the Bocage Museum'; Ferreira et al., 'A New Forensic Collection'; Rissech and Steadman, 'The Demographic, Socio-Economic and Temporal Contextualisation of the Universitat Autònoma de Barcelona Collection'.

22 'ossários', or ossuaries.

23 Cardoso, 'The Collection of Identified Human Skeletons Housed at the Bocage Museum.

24 Ibid.; E. Cunha and S. Wasterlain, 'The Coimbra Identified Osteological Collections', in G. Grupe and J. Peters (eds), Skeletal Series and Their Socio-Economic Context (Verlag, Rahden/Westf, 2007), pp. 23-33.

25 Ferreira et al. 'A New Forensic Collection'; H. F. V. Cardoso, L. Marinho, I. Caldas, K. Puentes, M. Andrade, A. Toso, S. Assis and T. Magalhães, 'Historical, Demographic, Curatorial and Legal Aspects of the BoneMedLeg Human Skeletal Reference Collection (Porto, Portugal)', Anthropologischer Anzeiger (accepted for publication); I. I. S. Escoval, 'Análise Métrica do Dimorfismo Sexual da Escápula na População Portuguesa:Um Novo Método de Diagnose Sexual', MSc thesis, University of Évora, 2016.

26 F. Alves Cardoso, 'With Whose Permission? Using Human Skeletal Tissue to Build Identified Skeletal Collections'. Paper presented at the ASA14 Decennial Conference: Anthropology and Enlightenment, Edinburgh, 2015. 
27 S. Payne, 'Handle With Care: Thoughts on the Return of Human Bone Collections', Antiquity, 78 (1994), 419-20; Muller et al. 'Dissection and Documented Skeletal Collections'; Alves-Cardoso, 'With Whose Permission?'; Cattaneo et al. 'A Modern Documented Italian Identified Skeletal Collection'.

28 Cardoso, 'The Collection of Identified Human Skeletons Housed at the Bocage Museum'

29 Ibid.

30 See Methods section.

31 W. A. Armstrong, 'The Use of Information about Occupation', in E. A. Wrigley (ed.), Nineteenth Century Society: Essays in the Use of Quantitative Methods for the Study of Social Data (Cambridge, Cambridge University Press, 1972), pp. 191-310.

32 H. F. V. Cardoso, 'Patterns of Growth and Development of the Human Skeleton and Dentition in Relation to Environmental Quality: A Biocultural Analysis of a Sample of 20th Century Portuguese Subadult Documented Skeletons', PhD dissertation, McMaster University, 2005.

33 Ibid.; Armstrong, 'The Use of Information about Occupation'.

34 Occupations considered ambiguous in terms of socioeconomic classification were removed from the sample.

35 F. A. Figueiredo, 'A Morte na Regiao De Lisboa Nos Princípios do Século XX', (Lisboa, Centro de Estudos Históricos (CEH) da Universidade Nova de Lisboa, 2006).

36 Albanese, 'Strategies for Dealing with Bias'.

37 G. V. Sousa, 'Ser e Estar Perante a Morte no Porto dos Séculos XIX e XX: Reflexos no Património Cemiterial', Lusitania Sacra, 6 (1994), 309-25; B. O. O. Xisto, 'Assunto Encerrado? Atitudes Contemporâneas Perante a Morte e a Cremaçāo em Lisboa', MA dissertation, University of Lisbon, 2012.

38 Xisto, 'Assunto Encerrado?'

39 Ibid.

40 Cardoso, 'The Collection of Identified Human Skeletons Housed at the Bocage Museum'

41 Figueiredo, 'A Morte na Regiao De Lisboa Nos Princípios do Século XX'.

42 Ibid.; F. Catroga, O céu da memória: Cemitério romântico e culto cívico dos mortos em Portugal, 1756-1911 (Lisboa, Minerva, 1999).

43 Through burial practices.

44 Through intentional amassing of individuals of low socioeconomic status.

45 P. Ariès, The Hour of Our Death. (Oxford, Oxford University Press, 1991). J. Goody and C. Poppi, 'Flowers and Bones: Approaches to the Dead in Anglo-American and Italian Cemeteries', Comparative Studies in Society and History, 36 (1994), 146-75.

46 H. Kenzler, 'Religion, Status and Taboo. Changing Funeral Rites in Catholic and Protestant Germany', in S. Tarlow (ed.), The Archaeology of Death in Post-medieval Europe (Walter de Gruyter \& Co., 2015), pp. 148-69, DOI: https://doi.org/10.1515/ 9783110439731-008. 
47 D. O’Rourke, 'Mourning Becomes Eclectic: Death of Communal Practice in a Greek Cemetery', American Ethnologist, 34:2 (2007), 387-402, DOI: 10.1525/ae.2007.34.2.387.

48 M. Heessels and E. Venbrux, 'Secondary Burial in the Netherlands: Rights, Rites and Motivations', Mortality, 14:2 (2009), 119-32, DOI: $10.1080 / 13576270902807771$.

49 E. Searcy, 'The Dead Belong to the Living: Disinterment and Custody of Dead Bodies in Nineteenth-Century America', Journal of Social History, 48:1 (2014), $112-34$.

50 H. Mytum, 'The Social History of the European Cemetery', Handbook of Death and Dying, 2 (2003), 801-9.

51 Goody and Poppi, 'Flowers and Bones'.

52 C. H. Lee Decker, 'Preparing for an Afterlife on Earth: The Transformation of Mortuary Behavior in Nineteenth-Century North America', in D. Gaimster and T. Majewski (eds), International Handbook of Historical Archaeology (New York, Springer 2009), pp. 141-57.

53 Mytum, 'The Social History of the European Cemetery'; Goody and Poppi, 'Flowers and Bones'.

54 Cardoso et al. 'Historical, Demographic, Curatorial and Legal Aspects of the BoneMedLeg Human Skeletal Reference Collection'.

55 Ferreira et al., 'A New Forensic Collection'.

56 N. T. C. R. Samelo, 'Aspectos Relativos à Tutela Post-Mortem da Personalidade Humana no Direito Civil', MA dissertation, University of Coimbra, 2016.

57 Cunha and Wasterlain, 'The Coimbra Identified Osteological Collections'.

58 M. Baiôa, P. J. Fernandes and F. R. Meneses, 'The Political History of Twentieth-Century Portugal', E-journal of Portuguese History, 1:2 (2003).

59 F. Catroga, Sociedade e Cultura Portuguesas. Volume 2 (Lisboa, Universidade Aberta, 1994).

60 M. L. Bandeira, Demografia e Modernidade. Família e Transição Demográfica em Portugal (Lisboa, Imprensa Nacional Casa da Moeda, 1996); A. Barreto, A Situação Social em Portugal, 1960-1999 (Lisboa, Imprensa de Ciências Sociais, 2000); T. R. Veiga, M. J. G. Moreira and A. A. Fernandes, 'Social Changes and Better Health Conditions of the Portuguese Population 1974-2000', Hygiea Internationalis, 4 (2004), 255-76.

61 Cardoso, 'The Collection of Identified Human Skeletons Housed at the Bocage Museum'.

62 Nystrom, 'The Bioarchaeology of Structural Violence'.

63 J. Ginter, 'Origins of the Odd Fellows Skeletal Collection: Exploring Links to Early Medical Training', Ontario Archaeology, 9 (2008), 85-8.

64 Cardoso, 'Patterns of Growth and Development of the Human Skeleton'; F. Alves-Cardoso and C. Henderson, 'The Categorisation of Occupation in Identi?ed Skeletal Collections: A Source of Bias?', International Journal of Osteoarchaeology, 23 (2013), 186-96, DOI: 10.1002/oa.2285.

65 Cardoso, 'Patterns of Growth and Development of the Human Skeleton'.

66 Ibid. 
67 Albanese, 'Strategies for Dealing with Bias'.

68 C. de la Cova, 'Race, Health, and Disease in 19th-Century-Born Males', American Journal of Physical Anthropology, 144 (2011), 526-37. C. de la Cova, 'Patterns of Trauma and Violence in 19th-Century-Born African-American and Euro-American Females', International Journal of Paleopathology, 2 (2012), 61-8.

69 J. Albanese, 'A Critical Review of the Methodology for the Study of Secular Change using Skeletal Data', in C. Ellis, N. Ferris, P. Timmins and C. White (eds), Papers in Honour of Michael Spence (Ontario, Archaeological Society Occasional Publication No. 9, 2010), pp. 161-80. 